\title{
HAZARD AND CONSEQUENCE ANALYSIS \\ FOR WASTE EMPLACEMENT AT THE WASTE ISOLATION PILOT PLANT
}

DOE/WIPP-96-2175

\author{
D. M . Gerstner \\ S. G. Clayton \\ R. F. Farrell
}

J. A. McCormick

C. Ortiz

D. L. Standiford
Waste Isolation Pilot Plant, P.O. Box 2078, Carlsbad, NM 88221 Phone: (505) 234- 8409, Fax: (505) 885-4562,
E-mail: gerstnd@wipp.carlsbad.nm.us

\section{DISCLAIMER}

\begin{abstract}
This report was prepared as an account of work sponsored by an agency of the United States Government. Neither the United States Government nor any agency thereof, nor any of their employees, makes any warranty, express or implied, or assumes any legal liability or responsibility for the accuracy, completeness, or usefulness of any information, apparatus, product, or process disclosed, or represents that its use would not infringe privately owned rights. Reference herein to any specific commercial product, process, or service by trade name, trademark, manufacturer, or otherwise does not necessarily constitute or imply its endorsement, recommendation, or favoring by the United States Government or any agency thereof. The views and opinions of authors expressed herein do not necessarily state or reflect those of the United States Government or any agency thereof.
\end{abstract}

Processing and final preparation of this report was performed by the Waste Isolation Pilot Plant Management and Operating Contractor for the U. S. Department of Energy under Contract No. DE-AC04-86AL31950. 


\title{
HAZARD AND CONSEQUENCE ANALYSIS FOR WASTE EMPLACEMENT AT THE WASTE ISOLATION PILOT PLANT
}

\author{
D. M. Gerstner, S. G. Clayton, R. F. Farrell, J. A. McCormick, C. Ortiz, D. L. Standiford \\ Waste Isolation Pilot Plant, P.O. Box 2078, Carlsbad, NM 88221 \\ Phone: (505) 234- 8409, Fax: (505) 885-4562, E-mail: gerstnd@wipp.carlsbad.nm.us
}

Facility Design

Administered by the U. S. Department of Energy (DOE) Carlsbad Area Office (CAO), the Waste Isolation Pilot Plant (WIPP) is designed to permanently dispose of transuranic (TRU) waste left from U.S. nuclear weapons research and production. Project facilities, located 26 miles east of Carlsbad, New Mexico, include disposal rooms mined on a horizon 2,150 feet beneath the earth's surface in a stable, ancient salt formation. The WIPP is designed to receive, handle, and dispose a maximum of $500,000 \mathrm{ft}^{3} / \mathrm{yr}$ of contact-handled (CH) TRU waste and 10,000 $\mathrm{ft}^{3} / \mathrm{yr}$ of remote-handled (RH) TRU waste. The CH TRU waste will be contained in 55-gallon drums and standard waste boxes. The WIPP facility is designed to have a disposal capacity for TRU waste of $6.2 \times 10^{6} \mathrm{ft}^{3}$. The WIPP disposal phase is scheduled to last 35 years.

The WIPP site is divided into three basic structure groups: surface structures, shafts, and subsurface structures. The WIPP surface structures accommodate the personnel, equipment, and support services required for the receipt, preparation, and transfer of waste from the surface to underground. The vertical shafts extending from the surface to the underground horizon are the waste shaft, the salt handling shaft, the air exhaust shaft, and the air intake shaft. TRU wastes will be transferred from the surface to the disposal horizon through the waste shaft using a standard mining industry hoisting arrangement. The underground areas consist of the waste disposal area, the support area, and the experimental area. The disposal area has four main entries (two entries for fresh air and two entries return air) and number of disposal rooms. The layout of the shafts and entries allows mining and disposal operations to proceed simultaneously.

\section{Facility Operations}

The principal operations of the WIPP involve the receipt and emplacement of TRU waste in the underground salt repository for disposal. Waste accepted for disposal must conform with the WIPP Waste Acceptance Criteria (WAC). Transporters carrying TRU waste arrive at the WIPP and are unloaded outside the Waste Handling Building (WHB). The shipments are surveyed for external contamination prior to movement into the WHB for unloading. Waste will be shipped to the WIPP in Nuclear Regulatory Commission (NRC) certified containers. After the $\mathrm{CH}$ TRU waste shipping container is inspected for contamination, the loaded shipping container is moved into the WHB and placed on a handling dock. The shipping container is opened, surveyed for radiation and contamination levels, and the waste containers are removed and placed on a facility pallet. This pallet is then transferred to the conveyance loading car, which is moved into the hoist cage in the waste shaft for transfer to the disposal horizon. At the disposal horizon, the pallet is removed from the hoist cage, placed on the underground transporter and moved to the CH TRU waste disposal room. In the disposal room, the containers are removed from the pallet and placed in the waste stack.

\section{Hazards and Consequence Analysis}

The CAO established and analyzed the safety bases for the design and operations described above, as documented in the WIPP Safety Analysis Report (SAR). Additional independent efforts are currently underway to assess the hazards associated with the long-term (10,000 year) isolation period as required by 40 CFR 191. The structure of the WIPP SAR is unique due to the hazards involved, and the agreement between the State of New Mexico and the DOE regarding SAR content and format. However, the hazards and accident analysis philosophy as contained in DOE-STD-3009-94 was followed as closely as possible, while adhering to state agreements. 
Hazards associated with WIPP waste receipt, emplacement, and disposal operations were systematically identified using a modified Hazard and Operability Study (HAZOP) technique. The WIPP HAZOP assessed the potential internal, external, and natural phenomena events that can cause the identified hazards to develop into accidents. The hazard assessment identified deviations from the intended design and operation of the waste handling system, analyzed potential accident consequences to the public and workers, estimated likelihood of occurrence, and evaluated associated preventative and mitigative features. It was concluded from the assessment that the proposed WIPP waste emplacement operations and design are sufficient to ensure safety of the public, workers, and environment, over the 35 year disposal phase.

Most operational accidents identified and analyzed are common to waste handling facilities, such as: (1) breach of waste containers during waste handling as a result of drops and punctures, (2) internal and external fires, (3) natural phenomena, specifically earthquake and tornado, and (4) external events such as range fires and aircraft crash. Drum drops and punctures were a result of equipment failure or human error involving waste handling equipment such as forklifts and transporters, and lifting equipment such as cranes. The quantitative frequency analysis identified human error as the primary cause for the initiating events. A sustained fire within an individual waste container in the WIPP Waste Handling Building or in the underground is the main contributor to risk of the operational accidents analyzed.

Accidents were also analyzed that are unique to a geological repository for nuclear waste, such as: (1) failure of the waste hoist system used to transport waste to the underground, and (2) collapse of the disposal room roof during emplacement operations. A potential accident currently being anaiyzed is the long-term buildup of hydrogen and methane gasses within the disposal rooms and detonation of the gas mixture. When compared to the energy sources available with waste handling operations, these accidents were the bounding accidents analyzed. However, using very conservative assumptions, the estimated, unmitigated consequences from these events are well within $25 \mathrm{rem}$.

The WIPP HAZOP identified a number of preventative and mitigative systems and controls that are currently in place for the bounding accidents, as well as the less severe but more likely waste handling accidents. The preventative systems and controls in place, which support the first layer of the WIPP defense-in-depth philosophy include the unique facility design and system, structure, and component (SSC) classification system, waste handling and emplacement procedures, operator training and qualification programs, the WIPP quality assurance program, and the WIPP WAC.

The mitigative systems and controls in place, which support the second layer of WIPP defense in depth, include Waste Handling Building and underground ventilation and associated HEPA filtration systems, and the WIPP Emergency Management program. However, based upon the result of the SAR accident unmitigated consequence analysis, and despite the use of very conservative accident analysis assumptions, the mitigative ventilation and filtration systems are not required for protection of the public or workers, and as such are neither safety class nor safety significant. Additionally, no Technical Safety Requirement Safety Limits, Operational Limits, or Surveillance Requirements are defined for the WIPP.

A fault tree analysis was performed for the WIPP Waste Hoist Brake System, intuitively the most important preventative system for a geological repository with the disposal horizon $2,150 \mathrm{ft}$ below the surface. Uncontrolled free fall of the waste hoist is prevented by the brake system. The fault tree analysis identified a number of design changes to the brake system that were implemented. The annual failure probability of the brake system is now less than $10^{-7} / \mathrm{yr}$. The SAR also used basic fault trees to analyze: (1) the WIPP WAC as the major preventative control for the sustained waste container fire scenario, and (2) the underground stability monitoring system that can be used to predict the possibility that an underground roof fall may occur, well ahead of time to allow the placements of barriers to prevent the release of radioactive material from crushed waste containers. The fault tree analyses indicate that with these preventative systems in place, the annual probability of a sustained waste container fire or a roof failure in the underground are less than 10.5/yr (extremely unlikely).

The long-term isolation phase analyses require that the DOE demonstrate that the repository will contain disposed waste such that the 40 CFR 191 quantitative release limits are met for radionuclides and hazardous constituents for future events during the 10,000 year performance period. The DOE's performance assessment (PA), is the probabilistic risk assessment tool for such an analysis. The PA will be included in the SAR when completed, and PA required engineered barriers and controls for long-term protection of the public and environment identified. 